\title{
Validation study of LQAS-2 in Uttar Pradesh behavior change management project
}

Arupendra Mozumdar

Population Council

Jaleel Ahmad

Population Council

M.E. Khan

Population Council

Follow this and additional works at: https://knowledgecommons.popcouncil.org/departments_sbsr-rh

Part of the Demography, Population, and Ecology Commons, Family, Life Course, and Society Commons, and the International Public Health Commons How does access to this work benefit you? Let us know!

\section{Recommended Citation}

Mozumdar, Arupendra, Jaleel Ahmad, and M.E. Khan. 2015. "Validation study of LQAS-2 in Uttar Pradesh behavior change management project." New Delhi: Population Council. 


\section{VALIDATION STUDY OF LQAS-2 IN UTTAR PRADESH BEHAVIOR CHANGE MANAGEMENT PROJECT}

Arupendra Mozumdar Jaleel Ahmad ME Khan

\section{POPULATION COUNCIL




\section{population
counchl \\ Ideas. Evidence. Impact.}

The Population Council confronts critical health and development issues-from stopping the spread of HIV to improving reproductive health and ensuring that young people lead full and productive lives. Through biomedical, social science, and public health research in 50 countries, we work with our partners to deliver solutions that lead to more effective policies, programs, and technologies that improve lives around the world. Established in 1952 and headquartered in New York, the Council is a nongovernmental, nonprofit organization governed by an international board of trustees.

Population Council

Zone $5 \mathrm{~A}$ India Habitat Centre

Lodi Road

New Delhi, 110003

India

Tel: +91-11-24642901/02

Fax: +91-11-43721409

email: info.india@popcouncil.org

popcouncil.org

Suggested citation: Mozumdar A, Ahmad J, Khan ME. 2015. "Validation study of LQAS-2 in UPBCM project." New Delhi, India: Population Council. 



\section{Table of Contents}

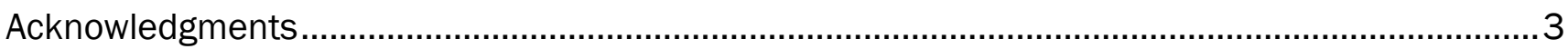

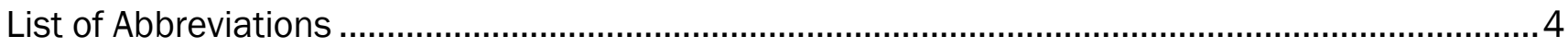

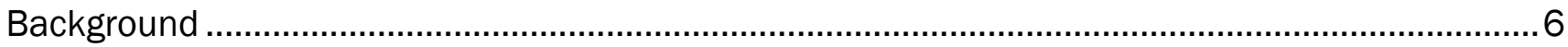

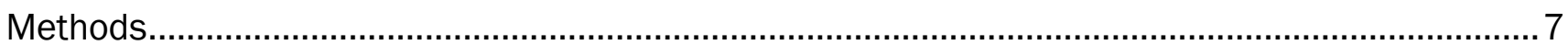

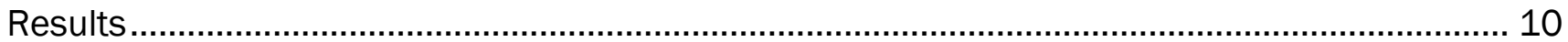

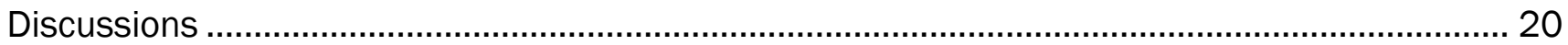

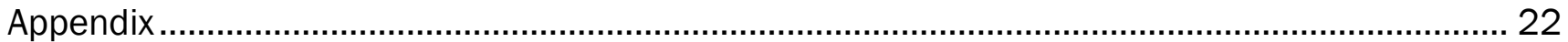




\section{Acknowledgments}

We are thankful for the financial support for this study provided by Bill and Melinda Gates Foundation (BMGF) under Uttar Pradesh Behavior Change Management (UPBCM) project. We are thankful to Rajiv Gandhi Mahila Vikas Pariyojna (RGMVP), especially to all the field level staffs for their cooperation and support to the every state of this study. We appreciate the help of the Public Health Foundation of India (PHFI) in providing help to develop the survey instruments; to share the field movement plans of their mentors, and to share LQAS-2 data for comparison. We appreciate the administrative and logistic support provided by Furthermore, we acknowledge with thanks the support provided by administrative and Project Coordinator of the Council for ensuring logistic support. 


\section{List of Abbreviations}

$\begin{array}{ll}\text { AAA } & \text { ASHA, ANM and AWW } \\ \text { AMC } & \text { Antenatal Cae } \\ \text { ANM } & \text { Auxiliary Nurse and Midwife } \\ \text { ASHA } & \text { Accredited Social Health Activist } \\ \text { AWW } & \text { Anganwadi Worker } \\ \text { BMGF } & \text { Bill and Melinda Gates Foundation } \\ \text { BO } & \text { Block Organization } \\ \text { CRDC } & \text { Community Resource Development Center } \\ \text { CRDI } & \text { Community Resource Development Institute } \\ \text { CV } & \text { Community Volunteers } \\ \text { EW } & \text { Eligible Woman } \\ \text { GP } & \text { Gram Panchayat } \\ \text { LQAS } & \text { Lot Quality Assurance Sampling } \\ \text { MLE } & \text { Management Learning and Evaluatin } \\ \text { PC } & \text { Population Council } \\ \text { PHFI } & \text { Public Health Foundation of India } \\ \text { PNC } & \text { Postnatal Care } \\ \text { RGMVP } & \text { Rajiv Gandhi Mahila Vikash Pariyojna } \\ \text { SHG } & \text { Self Help Group } \\ \text { UP } & \text { Uttar Pradesh } \\ \text { UPBCM } & \text { Uttar Pradesh Behavior Change Management } \\ \text { VO } & \text { Village Organization } \\ & \end{array}$




\section{Background}

Uttar Pradesh Behavior Change Management (UPBCM) project was started considering the potential and importance of community mobilization through Self Help Groups (SHG) of Rajiv Gandhi Mahila Vikash Pariyojna (RGMVP) for improving selected healthy behavior having direct bearing on the maternal, newborn and child health outcomes. Among different Management Learning and Evaluation (MLE) activities in the UPBCM project, multiple rounds of Lot Quality Assurance Sampling (LQAS) surveys were proposed to monitor the project activities and to help taking corrective measures to improve the project indicators across the project area. The other major purpose of the LQAS surveys in UPBCM project was to evaluate the diffusion of health messages in the project area from SHG members to SHG households and ultimately to non-SHG households.

In UPBCM project the periodic LQAS surveys are being conducted jointly by two of the consortium partners. Those are RGMVP and Public Health Foundation of India (PHFI). The Community Resource Development Institute (CRDI) personnel of RGMVP administer the survey. The CRDI personnel are responsible for building the capacity for SHG related activities and health interventions in a block. Experts of PHFI provide the technical support to RGMVP to conduct the survey and help to analyze the LQAS data for programmatic feedback.

The first round of LQAS was conducted in June, 2014. The second round of LQAS i.e. LQAS-2, was conducted in November - December, 2014 using a 17 item questionnaire (Appendix 1). It was conducted in 100 intervention blocks of UPBCM project. Each block was divided into 4 lots. However, depending of the size, population and geography of the block the number of lots varied sometimes between 3 to 5 . Each lot consisted of 5-8 Gram Panchayats (GPs), which coincides with zones allotted to each community volunteer (CV) of RGMVP.

For LQAS-2 from each lot 19 eligible women were randomly selected as respondents. The eligibility criteria for the respondents were the following: (1) the women who delivered a child within last six months, (2) the respondent should be a member of a SHG household i.e. belonging to a household with at least one member is also a member of an SHG belonging to RGMVP. The sampling frame to select the 19 eligible women (EW) was the registers of village organization (VO) of SHGs within a GP. It was calculated that at least $42 \mathrm{SHG}$ was required to achieve a sample of 19 eligible women. Therefore, the lots having less than $42 \mathrm{SHG}$ were removed from the sampling frame. Ultimately LQAS- 2 was conducted in 373 lots.

For LQAS-1 i.e. the first round of LQAS the CRDIs (at that time they were known as community health trainers) administered the survey in their own block. However, in LQAS-2 the each CRDI swapped their survey area with CRDI of her neighboring block so that they can administer the survey with less reporting bias.

As a part of technical support, PHFI gave the CRDIs a day-long training for LQAS survey. PHFI also arranged mentor support to the CRDIs to assure the quality of data collection in LQAS. Among the 4 lots within a block, in two lots a mentor supported each CRDI. The role of the mentor was to assist the CRDI administering the questions, to help explain questions to the respondents, if necessary, and to ensure correct recording of the answer given by the respondents. For each block generally mentor support was provided for the first five days and then the mentor was shifted to a different block.

The results of the first round of LQAS survey were shared with the consortium partners in MLE meeting held in September 2014. Since LQAS survey was administered by the community women, not by experienced fieldworkers, it was decided that the answers obtained by the CRDI staff sould be independently evaluated with two purposes; one to validate the accuracy of the response and second, in case of significant discrepancy how the CRDI could be more efficient and better trained to collect the data accurately. Bill and Melinda Gates Foundation (BMGF), the financial partner of the consortium views it as part of capacity building exercise of the RGMVP so that in future RGMVP could monitor their own program. Population Council (PC) the M\&E partner of the project was requested to conduct a validation study of the LQAS-2. 


\section{OBJECTIVES}

The validation study of LQAS-2 aimed to answer two research questions:

1. To examine the accuracy of the LQAS-2 data by CRDI with or without mentoring support, and

2. To understand the process of administering the LQAS by CRDIs

\section{Methods}

The aims of the validation study were to document the process of administration of the LQAS-2, accuracy of the data, and whether these two are different with or without mentor support.

Therefore, the validation study of the LQAS was conducted using two approaches:

(1) A validation survey among a subsample of women, who participated in LQAS-2, and

(2) Observation of the sampled interviews during the LQAS-2 survey

\section{VALIDATION SURVEY}

The validation survey was conducted among a subsample of participants of the LQAS-2. The design of the validation survey had two steps to maintain the randomness of the subsample and to make the subsample representative for LQAS-2 data. Those two steps were:

1. Calculation of required sample-size for the validation study

2. Selection of study area

\section{Sample-size}

The LQAS-2 was conducted in 100 blocks. Generally each block was divided into 4 lots. Sometimes the number of lots varied depending on the size of the block. Each lot corresponded with the zone allotted to a community Volunteer (CV), which looks after 5-6 GPs. In 100 blocks, LQAS-2 was conducted in 373 lots. From each lot 19 eligible women were interviewed. Therefore, the total number of respondents was $373 \mathrm{X}$ $19=7087$. Half of these interviews were mentor supported while the remaining half was done without mentors.

The required sample size for each study arm, with mentor and without mentor, was calculated with the following assumptions:

- $95 \%$ confidence level (c),

- $5 \%$ margin of error (E), and

- $50 \%$ response distribution ( $r$ ).

Using the following formulae including correction for finite population size $(\mathrm{N})$ the required sample size was:

$\mathrm{n}=\mathrm{Nx} /\left\{(\mathrm{N}-1) \mathrm{E}^{\wedge} 2+\mathrm{x}\right\}$

Where,

$$
\begin{array}{lll}
x & = & Z(c / 100)^{\wedge} 2 r(100-r) \\
E & = & \operatorname{Sqrt}\{(N-n) x / n(N-1)\}
\end{array}
$$

Therefore, to represent 3550 (N) LQAS interviews of each of the two types of lots, a subsample of 347 (n) was required. 


\section{Selection of study area}

It was decided to conduct the validation survey in two lots from each block; one block was considered where LQAS was done with mentor support and the other one without mentor support. From each selected lot, the survey team revisited all LQAS participants. Therefore, from each block there were $19 \times 2=38$ possible respondents. Therefore, to achieve the sample size of $347 \times 2=694$ it was necessary to conduct the survey in around 694/38=18.26 $\simeq 20$ blocks. However, expecting a high loss to follow-up, being conservative, the study was conducted in 25 blocks.

The 100 blocks of LQAS-2 spread over 33 districts of 8 CRDC zones of RGMVP project area. Since the number of districts and blocks vary by the Community Resource Development Center (CRDC), blocks were selected proportionately from each CRDC. The blocks in each CRDC were shorted alphabetically and then the required number of blocks from that CRDC was selected following a systematic random sampling. The distribution of the 25 blocks, selected for LQAS validation survey, is given in Table 1. Those blocks were from 18 districts of Uttar Pradesh (UP). The distribution of the districts in UP has been shown in Figure 1.

TABLE 1 Distribution of the structured observation in different blocks

\begin{tabular}{lcccc}
\hline CRDC & $\begin{array}{c}\text { Number of } \\
\text { districts in } \\
\text { LQAS }\end{array}$ & $\begin{array}{c}\text { Total number of } \\
\text { intervention blocks where } \\
\text { LQAS-2 is being done }\end{array}$ & $\begin{array}{c}\text { Number of blocks } \\
\text { selected for validation } \\
\text { (1/4th from each } \\
\text { CRDC) }\end{array}$ & $\begin{array}{c}\text { Number of } \\
\text { districts covered } \\
\text { in validation }\end{array}$ \\
\hline AMETHI & 4 & 28 & 7 & 3 \\
BANDA & 4 & 8 & 2 & 2 \\
GORAKHPUR & 7 & 12 & 3 & 3 \\
JHANSI & 4 & 9 & 2 & 2 \\
LUCKNOW & 4 & 9 & 2 & 2 \\
RAE BARELI & 3 & 20 & 5 & 2 \\
SHAHJAHANPUR & 2 & 4 & 1 & 1 \\
VARANASI & 5 & 10 & 3 & 3 \\
TOTAL & 33 & 100 & 25 & 18 \\
\hline
\end{tabular}

Since from each block two lots were included as the study area for validation, the survey was done in 50 lots (25 blocks X 2 lots). All the EW from each selected lot was approached to participate for validation interview. Among a possible total of around 950 EWs (50 lots*19 EW) 668 were interviewed in validation survey. Of those, 332 were from mentored lots and 336 from non-mentored lot. Same questions of LQAS -2 survey were included in the survey instrument of the validation survey to maintain the consistency between the two surveys.

The major reason for the lost to follow-up was unavailability of the respondents in their home. The unavailability was mostly due to respondent's visit to their parents' home. Moreover, the survey coincided with Makar Sankranti festival, when the women generally visit and stay in their parent's home.

\section{FIGURE 1 Distribution of district in LQAS validation study}

- Allahabad
- Amethi
- Banda
- Barabanki
- Basti
- Faizabad
- Fatehpur
- Gonda
- Hamirpur
- Jhansi
- Lalitpur
- Lucknow
- Mirzapur
- Raebareli
- Sant Kabir Nagar
- Shahajanpur
- Sultanpur
- Varanasi

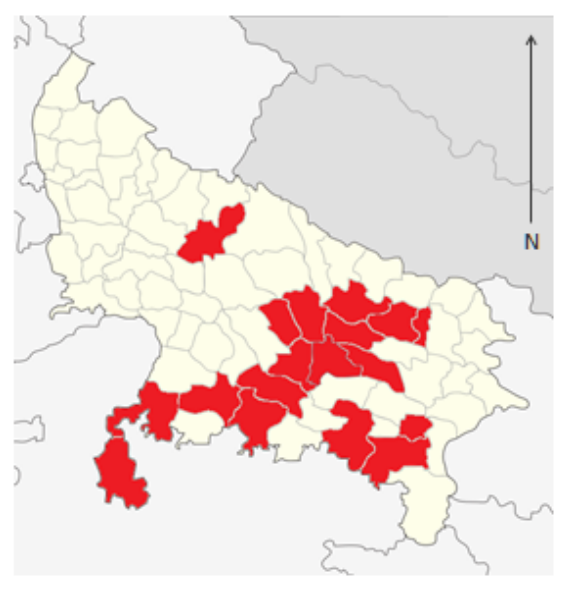




\section{OBSERVATION OF THE SAMPLED INTERVIEWS}

To conduct the observation an eight item observation checklist was developed for uniform observation of the interviews (See Appendix-2 for details). The eight observation items included :

1. Proper introduction of the survey and explanation of the purpose of the study

2. Asking the question in own way without changing the meaning

3. Asked the question clearly

4. Giving away answers while explaining any question

5. Reading out the answers

6. Showing the pictorial answers

7. Marking the answers correctly

8. Prior availability of the list of the eligible women

Three trained research assistance (RA) observed the LQAS interviews, done by the CRDIs staff using the observation checklist. The observers took the consent of all the participants and the LQAS interviewers before doing the observations and informed them that they will be watched during the LQAS interview but their privacy will be maintained and the observation is being done to understand the process of the interviews. The observers did not intervene in case of any mistake during the interview or recording of the answer choices. They completed the checklist based on their observation and also recorded significant qualitative observations after the interview.

All observations were conducted in second and third week of November 2014. The observations were conducted in 12 randomly selected blocks spreading over 7 districts. A total of 13 CRDIs' interviews were observed. Of those 6 had mentor support, and 7 did not have any mentor support during LQAS interviews at the time of the observation. Total 65 observations of the LQAS interviews were done spreading over 20 GPs. Of those observations 35 LQAS interviews were mentor supported and 30 LQAS interviews were without mentors.

\section{ANALYSES PLAN}

The data were analyzed using the following analyses plan. These include:

- The comparison of results of validation survey between lots with and without mentor support

- Since the same respondents are being followed up in validation survey, the degree of consistency for each program related indicators was calculated

- Percentage of consistency, false positive rate, Cohen's Kappa were calculated for mentor supported and non-mentor supported lots

- Comparison of the results of the observations, on how CRDI staff administered the LQAS questionnaire both in mentor supported LQAS interviews and the interviews without mentor support 


\section{Results}

In this section findings of the LQAS validation study have been presented. The section begins with presentation of background characteristics of the respondents of validation study, followed by the estimates of different program related variables. The pattern of the consistency in LQAS-2 in comparison with validation survey has been presented next. The section ends with the presentation of the result of the observation study to suggest the possible improvements required for future rounds of LQAS in UPBCM project.

\section{FINDINGS OF THE VALIDATION SURVEY}

The present section gives the LQAS validation survey results. First, the background characteristics of the respondents have been presented followed by the estimates of the key outcome variables. Then the comparison of the results of LQAS-2 and validation survey has been tabulated.

\section{Background characteristics of the respondents}

The background characteristics of the respondents are presented in Table 2. Most of the respondents had a child aged between 2-5 months. In LQAS2 one of the criteria for eligible woman was having a child less than 6 months. The validation study was conducted about a month after the end of the LQAS-2. Therefore, at the time of the validation study data collection some of the children were more than 6 months old. Majority of the respondents were literate. More than half of the respondent herself were member of SHG. Most of the
TABLE 2 Distribution of the structured observation in different blocks

\begin{tabular}{|c|c|c|c|}
\hline $\begin{array}{l}\text { Background } \\
\text { characteristics }\end{array}$ & $\begin{array}{c}\text { Mentor } \\
\text { supported lots } \\
(n=332)\end{array}$ & $\begin{array}{l}\text { Non-mentor } \\
\text { supported lots } \\
(n=336)\end{array}$ & $\begin{array}{l}\text { P value } \\
\text { (Z-test) }\end{array}$ \\
\hline \multicolumn{4}{|l|}{ Age of the child, \% } \\
\hline 0-1 month & 12.0 & 12.5 & NS \\
\hline 2-3 months & 33.7 & 30.1 & NS \\
\hline 4-5 months & 28.6 & 30.7 & NS \\
\hline 6 months or above & 25.6 & 26.8 & NS \\
\hline \multicolumn{4}{|l|}{ Education status, \% } \\
\hline Cannot read/ write & 45.2 & 43.5 & NS \\
\hline Can read/ write & 3.9 & 5.1 & NS \\
\hline Can both read \& write & 50.9 & 51.5 & NS \\
\hline \multicolumn{4}{|l|}{ SHG membership, \% } \\
\hline Self & 55.4 & 50.3 & NS \\
\hline Mother-in-law & 33.4 & 33.0 & NS \\
\hline Others & 11.1 & 16.7 & 0.036 \\
\hline \multicolumn{4}{|l|}{ Caste, \% } \\
\hline Scheduled caste/ tribe & 35.5 & 42.9 & 0.049 \\
\hline Other backward class & 50.6 & 44.6 & NS \\
\hline Other & 13.9 & 12.5 & NS \\
\hline
\end{tabular}
respondents belonged to disadvantaged groups such as scheduled castes or scheduled tribes or other backward classes. Most of the background characteristics of the respondents did not differ between mentorsupported zones and non-mentor-supported zones. This indicates the distribution of the respondents were unbiased between the two zones.

There were a high number of lost to follow-up in the validation survey from LQAS-2 (about 30\%). The reason for lost to follow-up have been given earlier in the method section. However, the background characteristics of the drop-outs and followed-up participants did not show a significant difference (not presented here). Therefore, the current followed-up respondents are a representative sub-sample of the LQAS-2 participants in the selected study area.

\section{Estimates of the program related variables}

In LQAS-2, there were questions on both outcome variables and process variables. The outcome variables were related to four different types of family health indicators including: (1) maternal health practices, (2) knowledge of maternal and newborn danger signs, (3) home based newborn practices, and (4) knowledge of childcare. Apart from the outcome variables there were 3 process variables in the LQAS survey. Those included (1) source of knowledge on maternal and newborn health, (2) receipt of the maternal and newborn health related leaflets and letters, and (3) participation in health discussion in pregnancy during pregnancy. 


\section{ANC and hospital delivery}

Table 3 presents the estimates of maternal health related practices separated for mentorsupported and nonmentor-supported lots. About $60 \%$ of the respondents of the both types of LQAS lots received 3 or more antenatal care (ANC) check-ups. Nearly 10 percent respondents did not receive any ANC check-ups. About 45 percent of the respondents consumed 100 or more iron and folic acid (IFA) tablets during their last pregnancy. However,

TABLE 3: Estimates of practices related to maternal health

\begin{tabular}{lccc}
\hline Outcome variables & $\begin{array}{c}\text { Mentor } \\
\text { supported } \\
\text { lots }(\mathrm{n}=332)\end{array}$ & $\begin{array}{c}\text { Non-mentor } \\
\text { supported } \\
\text { lots }(\mathrm{n}=336)\end{array}$ & $\begin{array}{c}\text { P value } \\
\text { (Z-test) }\end{array}$ \\
\hline Number of ANC check-up, \% & 8.1 & 10.7 & NS \\
\hline O ANC check-up & 31.0 & 28.3 & NS \\
1-2 ANC check-up & 60.8 & 61.0 & NS \\
3 or more ANC check-up & 18.4 & 20.5 & NS \\
IFA tablets consumed, \% & 36.1 & 35.2 & NS \\
O IFA tablet & 45.5 & 44.3 & NS \\
1 - 99 IFA tablets & 88.0 & 88.1 & NS \\
100 or more IFA tablets & & & NS \\
Hospital delivery, \% & 28.3 & 30.1 & NS \\
Delivery preparedness, \% & 67.8 & 65.5 & NS \\
Identification of health & 79.5 & 79.5 & NS \\
facility & 20.8 & 23.2 & NS \\
Arrangement of transport & 41.3 & 42.6 & \\
Saving money & & & \\
Care for children at home & & & \\
Accompany of family & members & &
\end{tabular}

nearly 20 percent did not consume any IFA tablets during their last pregnancy. A very high percentage (88 percent) of child delivery happened in private or government hospitals.Saving money prior to delivery was the most common (80 percent) arrangement done by the respondents to prepare against any pregnancy related or delivery related complications.

That was followed by arrangement of transport (nearly 65 percent). Care for children at home was the least common among delivery related preparations. None of the percentage of delivery related preparations were significantly different between mentor supported and non-mentor supported lots.

\section{Knowledge of danger signs}

The prevalence of TABLE 4 Estimates of knowledge of maternal and newborn danger signs

\begin{tabular}{|c|c|c|c|c|}
\hline $\begin{array}{l}\text { knowledge of } \\
\text { maternal danger } \\
\text { signs and newborn }\end{array}$ & Outcome variables & $\begin{array}{c}\text { Mentor } \\
\text { supported } \\
\text { lots }(n=332)\end{array}$ & $\begin{array}{c}\text { Non-mentor } \\
\text { supported } \\
\text { lots }(n=336)\end{array}$ & $\begin{array}{l}\text { P value } \\
\text { (Z-test) }\end{array}$ \\
\hline danger signs has & Danger signs of pregnancy, \% & & & \\
\hline been presented in & Vaginal bleeding & 49.4 & 49.1 & NS \\
\hline Table 4. Most & Bleeding after delivery & 30.4 & 30.7 & NS \\
\hline commonly & Swelling/ headache/ blurred vision & 43.1 & 45.2 & NS \\
\hline ported maternal & Labor pain $>12 \mathrm{hrs}$ & 16.0 & 22.0 & 0.047 \\
\hline inger sing was & Faintness & 14.2 & 13.7 & NS \\
\hline ginal discharge & Vaginal discharge/ foul smell & 52.4 & 52.1 & NS \\
\hline foul smell (52 & Danger signs of newborn, \% & & & \\
\hline rcent) The other & No breastfeeding & 16.6 & 20.5 & NS \\
\hline & Redness of cord/ discharge & 6.0 & 9.8 & NS \\
\hline n & Chest drawing in/ pneumonia & 58.7 & 65.5 & NS \\
\hline orted mate & Sudden pulling & 5.7 & 8.6 & NS \\
\hline 0 & High fever & 66.3 & 63.1 & NS \\
\hline ginal bleedin & Diarrhea & 58.7 & 53.0 & NS \\
\hline
\end{tabular}
and swelling of hand and feet or headache or blurred vision during pregnancy.

Among the danger signs of newborn child the most commonly reported sign was high fever, reported by over 60 percent of respondents. The other two commonly reported newborn danger signs were chest in-drawing and diarrhea. 
Among the different danger signs, reporting of only one danger sign was significantly different in between the two types of lots and that danger sing was prolonged labor pain of more than 12 hours.

\section{Home based newborn care practices}

Table 5 presents the estimates for different home based newborn care practices separated for mentor supported lots and non-mentor supported lots. The different practices of newborn care included thermal care, correct knowledge of $\mathrm{KMC}$, and excusive breastfeeding within last 24 hours, cord care, and PNC within a week.
TABLE 5 Estimates of home based newborn practices

\begin{tabular}{|c|c|c|c|}
\hline Outcome variables & $\begin{array}{c}\text { Mentor } \\
\text { supported } \\
\text { lots }(n=332)\end{array}$ & $\begin{array}{l}\text { Non-mentor } \\
\text { supported } \\
\text { lots }(n=336)\end{array}$ & $\begin{array}{l}P \text { value } \\
\text { (Z-test) }\end{array}$ \\
\hline \multicolumn{4}{|l|}{ Thermal care, \% } \\
\hline Gave KMC & 40.4 & 45.5 & NS \\
\hline Wrapped by warm cloths & 69.0 & 61.3 & 0.036 \\
\hline Keeping fire in room & 1.8 & 3.3 & NS \\
\hline Correct knowledge or KMC, \% & 44.0 & 50.3 & NS \\
\hline Exclusive breastfeeding (24 h) \% & 74.7 & 77.4 & NS \\
\hline Delayed bathing (> 2 days), $\%$ & 58.4 & 59.8 & NS \\
\hline \multicolumn{4}{|l|}{ Cord care to dry cord stump, \% } \\
\hline Oil & 19.6 & 16.7 & NS \\
\hline Talcum powder & 10.2 & 10.7 & NS \\
\hline Turmeric/ Ash/ Beatle nut etc. & 8.4 & 8.4 & NS \\
\hline Nothing & 66.9 & 68.2 & NS \\
\hline PNC check-up within 7 days, $\%$ & 53.6 & 61.0 & NS \\
\hline
\end{tabular}

The most commonly reported thermal care practice was wrapping the newborn child with warm cloths. Respondents of mentor supported lots reported significantly higher prevalence of this practice. More than 40 percent women reported that they gave KMC to their newborn child. Nearly half of the respondents correctly described the method of giving KMC. Nearly 60 percent respondents reported that they bathed their newborn child after 2 days of delivery. Over 65 percent respondent reported that they did not put anything on the cord stump of the newborn child to make it dry. Over 50 percent of the respondents reported that their child received PNC check-up within 7 days of delivery.

\section{Knowledge of child care}

The prevalence of TABLE 6 Estimates of knowledge of child care knowledge of diarrhea prevention and ailments/ symptoms of pneumonia has been presented in Table 6. Giving salt and sugar solution to prevent diarrhea was the most common answer reported by the respondents. The knowledge on use of zinc tablet for diarrhea prevention was very low (about 9 percent).

\begin{tabular}{lccc}
\hline Outcome variables & $\begin{array}{c}\text { Mentor } \\
\text { supported } \\
\text { lots }(\mathrm{n}=332)\end{array}$ & $\begin{array}{c}\text { Non-mentor } \\
\text { supported } \\
\text { lots }(\mathrm{n}=336)\end{array}$ & $\begin{array}{c}\text { P value } \\
\text { (Z-test) }\end{array}$ \\
\hline $\begin{array}{l}\text { Knowledge of diarrhea } \\
\text { prevention, \% }\end{array}$ & & & \\
$\quad$ Give salt and sugar solution & 50.6 & 57.1 & NS \\
$\quad$ Give ORS & 21.7 & 22.6 & NS \\
$\quad$ Zinc tablet/ medicine & 9.3 & 8.6 & NS \\
$\begin{array}{l}\text { Correct knowledge of } \\
\text { pneumonia, } \%\end{array}$ & & & \\
$\quad$ Fast breathing & 49.7 & 54.2 & NS \\
$\quad$ Chest drawing in & 39.2 & 47.0 & 0.041 \\
$\quad$ Sound in breathing & 19.0 & 24.1 & NS \\
\hline
\end{tabular}

Among different symptoms of pneumonia, fast breathing was reported by about half of the respondents. The other common answer was in-drawing of the chest and significantly higher proportion of respondents of the non-mentor supported lots reported their knowledge of this symptom.

\section{Estimates of process variables}

Table 7 presents the estimates of output variables. About 60 percent of the respondents reported SHG and Swasth Sakhis as their sources of knowledge for maternal and child health. Around 20 percent respondent reported their mother-in-laws and ASHA/ ANM/AWW as their source of knowledge. Higher percentage of the respondents reported receipt of the 'Good Luck' letter and 'Congratulation' letter than leaflets of maternal and newborn health. Nearly half of the respondents reported that they took part in health discussions in any SHG meeting during their last pregnancy. 
Most of the outcome variables and process variables did not show any significant difference in between mentor supported lots and non-mentor supported lots. The observation results however, had shown that quality of data was relatively better Participated in Health discussion, \% TABLE 7 Estimates of process variables

\begin{tabular}{lccc}
\hline Output variables & $\begin{array}{c}\text { Mentor } \\
\text { supported } \\
\text { lots }(n=332)\end{array}$ & $\begin{array}{c}\text { Non-mentor } \\
\text { supported } \\
\text { lots }(n=336)\end{array}$ & $\begin{array}{c}\text { P value } \\
\text { (Z-test) }\end{array}$
\end{tabular}

\section{Source of knowledge, \%}

SHG/ Swasth Sakhi $\quad 59.6 \quad 64.0 \quad$ NS

$\begin{array}{llll}\text { Mother-in-law } & 23.8 & 21.1 & \text { NS }\end{array}$

$\begin{array}{llll}\text { Local doctor } & 4.2 & 4.8 & \text { NS }\end{array}$

AAA

Received leaflets/ letters, $\%$

$23.8 \quad 23.2 \quad$ NS

$\begin{array}{llll}\text { Maternal health leaflet } & 33.4 & 29.2 & \text { NS }\end{array}$

Newborn health leaflet $\quad 22.9 \quad 26.5 \quad$ NS

Good luck letter $\quad 44.9 \quad 39.9 \quad$ NS

$\begin{array}{llll}\text { Congratulation letter } & 45.5 & 36.3 & 0.015\end{array}$

than for interview with mentor as compared to without mentor. Given the small number of observations made, one could rely more on the results of the validation survey. Therefore, it can be concluded that the respondents practicing certain maternal and child health related behavior were evenly distributed in both types of lots within a block; and there was no significant bias in the validation data between the lots with or without mentor support in validation study.

\section{DEGREE OF CONSISTENCY IN LQAS-2 IN COMPARISON WITH VALIDATION SURVEY}

Same respondents participated both in LQAS-2 and in validation survey. Therefore, the degree of consistency between the two surveys has been calculated to examine the pattern of errors in LQAS-2, if any, and whether the pattern differs between mentor supported and non-mentor supported lots.

Calculation of consistency between LQAS-2 results and the findings of the validation survey has been done using the process explained in following example. In validation survey 588 respondents out of 668 total respondents reported that they delivered their last child in a hospital. So the rest i.e. 80 respondents delivered their last child at home However, in LQAS-2 the distribution of the place of last child delivery of the same respondents were 599 as hospital delivery and 69 as home. So, if the two sets of data are tabulated we get the distribution of the place of delivery as shown in Table 8.

The two cells in green shade represent the consistency in reporting of place of delivery between the two surveys i.e. LQAS-2 and validation survey. The cell in red shade represents the false positives that mean those respondents actually did not have a

TABLE 8 Distribution of place of delivery between two surveys (example of consistency)

\begin{tabular}{|c|c|c|c|c|}
\hline & \multicolumn{2}{|c|}{ LQAS-2 } & \multirow[b]{2}{*}{ Total } \\
\hline & & Home/ Other & Hospital & \\
\hline \multirow{2}{*}{$\begin{array}{l}\text { Validation } \\
\text { survey }\end{array}$} & \multirow{2}{*}{$\begin{array}{c}\text { Home/ Other } \\
\text { Hospital } \\
\text { Total }\end{array}$} & $56(a)$ & $24(b)$ & \multirow{2}{*}{$\begin{array}{c}80(a+b) \\
588(c+d) \\
668(N)\end{array}$} \\
\hline & & $\frac{13(c)}{69(a+c)}$ & $575(d)$ & \\
\hline
\end{tabular}
hospital delivery but in LQAS-2 they were classified as cases of hospital delivery. The cell in white shade represents false negatives, who actually had hospital delivery but in LQAS-2 they were reported as home delivery. From the program point of view, false positives are more alarming because encouraging people for the hospital delivery is one of the important program activities. So, more false positives will over-report the impact of the project.

The percentage of consistency, false positive rate and Cohan's Kappa are calculated for each of the program related variables separately for mentor-supported lots and non-mentor supported lots. The calculation of those statistics has been described using the example given in Table 8.

Percentage of consistency $=(a+d) / N=631 / 668=0.945$ i.e. $94.5 \%$

The false positive rate $=a /(a+c)=24 / 80=0.3$ i.e. $30.0 \%$ 
Cohen's kappa $(k)=(\mathrm{Pa}-\mathrm{Pe}) /(1-\mathrm{Pe})$

Where, $\mathrm{Pa}$ (probability of agreement $)=(\mathrm{a}+\mathrm{d}) / \mathrm{N}=(56+575) / 668=0.945$

Pe (probability of agreement by chance)

$$
\begin{aligned}
& =\{(a+c) / N\} *(a+b) / N\}+\{(b+d) / N\} *\{(c+d) / N\} \\
& =\left\{(a+c) *(a+b) / N^{2}\right\}+\left\{(b+d) *(c+d) / N^{2}\right\} \\
& =[\{(a+c) *(a+b)\}+\{(b+d) *(c+d)\}] / N^{2} \\
& =\{(69 * 80)+(599 * 588)\} / 668^{2} \\
& =(5520+352212) / 446224=357732 / 446224=0.802
\end{aligned}
$$

So, $k=(0.945-0.802) /(1-0.802)=0.721$

Table 9 shows the percentage of consistency, false positive rates, and Cohen's kappa for maternal health related variables separately for mentor supported lots and non-mentor supported lots. The highest degree of agreement was reported for hospital delivery $(k>0.8)$. The degree of consistency were also high for receipt of 3 or more ANC, consumption of 100 or more IFA tablets, saving money as delivery preparation. For mentor supported lots a significantly higher percentage of consistency was for identification of health

\begin{tabular}{|c|c|c|c|c|c|c|}
\hline \multirow[b]{2}{*}{ Program related variables } & \multicolumn{3}{|c|}{ Mentor supported lots $(n=332)$} & \multicolumn{3}{|c|}{ Non-mentor supported lots $(n=336)$} \\
\hline & $\begin{array}{c}\% \text { of } \\
\text { consistency }\end{array}$ & $\begin{array}{c}\text { False } \\
\text { positive } \\
\text { rate }\end{array}$ & $\begin{array}{l}\text { Cohen's } \\
\text { kappa }\end{array}$ & $\begin{array}{c}\% \text { of } \\
\text { consistency }\end{array}$ & $\begin{array}{l}\text { False } \\
\text { positive } \\
\text { rate }\end{array}$ & $\begin{array}{l}\text { Cohen's } \\
\text { kappa }\end{array}$ \\
\hline 3 or more ANC & 76.5 & 35.4 & 0.50 & 72.3 & 35.1 & 0.42 \\
\hline 100 or more IFA consumed & 72.9 & 30.4 & 0.46 & 74.1 & 27.3 & 0.48 \\
\hline Hospital delivery & 96.1 & $20.0 *$ & 0.81 & 92.9 & $40.0 *$ & 0.63 \\
\hline \multicolumn{7}{|l|}{ Delivery preparedness } \\
\hline Identification of health facility & $48.2 *$ & $61.8 *$ & 0.08 & $36.6 *$ & $77.4 *$ & 0.06 \\
\hline Arrangement of transport & 67.8 & 65.4 & 0.20 & 67.9 & 71.6 & 0.19 \\
\hline Saving money & 79.8 & $64.7 *$ & 0.30 & 80.1 & $87.0 *$ & 0.15 \\
\hline Care for children at home & 56.6 & 47.5 & 0.16 & 57.1 & 48.8 & 0.19 \\
\hline Accompany of family members & 58.1 & 46.7 & 0.18 & 55.7 & 52.3 & 0.14 \\
\hline
\end{tabular}
facility as delivery preparedness. For non-mentor supported lots significantly higher false positive rates for three out of eight variables of maternal health practices.

TABLE 9 Measurement of consistency of the LQAS-2 data in comparison with validation survey for maternal health related practices

* Significant difference between mentor supported lots and non-mentor supported lots

Table 10 shows the degree of consistency between two surveys for knowledge of different maternal and newborn danger signs separately for mentor supported lots and non-mentor supported lots. Overall the percentages of consistency varied between 60 to 70 percent. The degree of agreement between the two surveys for these knowledge related variables were poor $(k<0.2)$ to fair $(k 0.2$ to $<0.4)$. Mentor supported lots had significantly higher percentage of consistency for no breasting and redness of cord as newborn danger signs. For non-mentor supported lots significantly higher false positive rates for seven out of twelve variables of maternal and newborn danger signs. 
TABLE 10 Measurement of consistency of the LQAS-2 data in comparison with validation survey for knowledge of maternal and newborn danger signs

\begin{tabular}{|c|c|c|c|c|c|c|}
\hline \multirow[b]{2}{*}{ Program related variables } & \multicolumn{3}{|c|}{ Mentor supported lots $(n=332)$} & \multicolumn{3}{|c|}{ Non-mentor supported lots $(n=336)$} \\
\hline & $\begin{array}{c}\% \text { of } \\
\text { consistency }\end{array}$ & $\begin{array}{c}\text { False } \\
\text { positive } \\
\text { rate }\end{array}$ & $\begin{array}{l}\text { Cohen's } \\
\text { kappa }\end{array}$ & $\begin{array}{c}\% \text { of } \\
\text { consistency }\end{array}$ & $\begin{array}{l}\text { False } \\
\text { positive } \\
\text { rate }\end{array}$ & $\begin{array}{c}\text { Cohen's } \\
\text { kappa }\end{array}$ \\
\hline \multicolumn{7}{|l|}{ Danger signs of pregnancy } \\
\hline Vaginal bleeding & 60.8 & 47.6 & 0.22 & 57.7 & 57.3 & 0.16 \\
\hline Bleeding after delivery & 63.0 & 34.2 & 0.20 & 58.6 & 42.5 & 0.16 \\
\hline Swelling/ headache & 57.5 & $51.9 *$ & 0.17 & 52.4 & $68.5^{*}$ & 0.09 \\
\hline Labor pain $>12 \mathrm{hrs}$ & 57.8 & 43.7 & 0.12 & 52.7 & 51.5 & 0.10 \\
\hline Faintness & 71.4 & $27.0 *$ & 0.23 & 66.1 & $35.9 *$ & 0.23 \\
\hline Vaginal discharge/ foul smell & 62.7 & $48.1^{*}$ & 0.25 & 59.8 & $60.2^{*}$ & 0.18 \\
\hline \multicolumn{7}{|l|}{ Danger signs of newborn } \\
\hline No breastfeeding & $59.9 *$ & $37.5 *$ & 0.06 & $49.7 *$ & $53.9 *$ & 0.06 \\
\hline Redness of cord/ discharge & $78.0 *$ & $18.6 *$ & 0.03 & $71.1^{*}$ & $26.7 *$ & 0.13 \\
\hline Chest drawing in/ pneumonia & 62.3 & $55.5 *$ & 0.20 & 59.2 & $62.3 *$ & 0.01 \\
\hline Sudden pulling & 75.3 & 22.4 & 0.06 & 75.0 & 23.1 & 0.17 \\
\hline High fever & 66.9 & $74.1^{*}$ & 0.16 & 63.1 & $86.3 *$ & 0.07 \\
\hline Diarrhea & 56.9 & 67.9 & 0.07 & 56.8 & 77.2 & 0.10 \\
\hline
\end{tabular}

* Significant difference between mentor supported lots and non-mentor supported lots

Table 11 shows the degree of consistency between two surveys for home based newborn care practices separately for mentor supported lots and non-mentor supported lots. Overall the percentages of consistency were mostly around 70 percent. The degree of agreement between the two surveys for home based newborn care related variables were fair $(k 0.2$ to $<0.4)$ to moderate $(k 0.4$ to $<0.6)$. Mentor supported lots had significantly higher percentage of consistency for practice of KMC and warming the room with fire. For non-mentor supported lots significantly higher false positive rates for five out of eight variables of home based newborn care.

TABLE 11 Measurement of consistency of the LQAS-2 data in comparison with validation survey for practice of home based newborn care

\begin{tabular}{|c|c|c|c|c|c|c|}
\hline \multirow[b]{2}{*}{ Program related variables } & \multicolumn{3}{|c|}{ Mentor supported lots $(n=332)$} & \multicolumn{3}{|c|}{ Non-mentor supported lots $(n=336)$} \\
\hline & $\begin{array}{c}\% \text { of } \\
\text { consistency }\end{array}$ & $\begin{array}{c}\text { False } \\
\text { positive } \\
\text { rate }\end{array}$ & $\begin{array}{c}\text { Cohen's } \\
\text { kappa }\end{array}$ & $\begin{array}{c}\% \text { of } \\
\text { consistency }\end{array}$ & $\begin{array}{c}\text { False } \\
\text { positive } \\
\text { rate }\end{array}$ & $\begin{array}{c}\text { Cohen's } \\
\text { kappa }\end{array}$ \\
\hline \multicolumn{7}{|l|}{ Thermal care } \\
\hline Gave KMC & $61.7 *$ & $40.4 *$ & 0.24 & $53.9 *$ & $59.6^{*}$ & 0.10 \\
\hline Wrapped by warm cloths & 69.0 & 90.3 & 0.07 & 62.8 & 89.2 & 0.08 \\
\hline Keeping fire in room & $88.9 *$ & $10.1^{\star}$ & 0.07 & $80.6 *$ & $18.2^{\star}$ & 0.06 \\
\hline Correct knowledge or KMC & 64.2 & $44.1^{*}$ & 0.30 & $60.1^{*}$ & $58.7^{*}$ & 0.20 \\
\hline Exclusive breastfeeding,, (24 h) & 73.8 & 64.3 & 0.24 & 73.5 & 77.6 & 0.13 \\
\hline Delayed bathing (> 2 days) & 70.8 & 56.5 & 0.36 & 66.7 & 57.8 & 0.27 \\
\hline Clean Cord care & 71.4 & $44.5^{*}$ & 0.35 & 69.6 & $64.5^{*}$ & 0.23 \\
\hline PNC check-up within 7 days & 73.5 & $47.7 *$ & 0.47 & 67.0 & $64.9 *$ & 0.28 \\
\hline
\end{tabular}

* Significant difference between mentor supported lots and non-mentor supported lots

Table 12 shows the degree of consistency between two surveys for knowledge of child care practices separately for mentor supported lots and non-mentor supported lots. Overall the percentages of consistency were mostly around 70 percent. The degree of agreement between the two surveys for knowledge of child care variables were poor $(k<0.2)$ to fair $(k 0.2$ to $<0.4)$. Mentor supported lots had 
significantly higher percentage of consistency for giving ORS for diarrhea and sound in breathing for pneumonia. For non-mentor supported lots significantly higher false positive rates for five out of six variables of home based newborn care.

TABLE 12 Measurement of consistency of the LQAS-2 data in comparison with validation survey for knowledge of child care

\begin{tabular}{|c|c|c|c|c|c|c|}
\hline \multirow[b]{2}{*}{ Program related variables } & \multicolumn{3}{|c|}{ Mentor supported lots $(n=332)$} & \multicolumn{3}{|c|}{ Non-mentor supported lots $(n=336)$} \\
\hline & $\begin{array}{c}\% \text { of } \\
\text { consistency }\end{array}$ & $\begin{array}{l}\text { False } \\
\text { positive } \\
\text { rate }\end{array}$ & $\begin{array}{c}\text { Cohen's } \\
\text { kappa }\end{array}$ & $\begin{array}{c}\% \text { of } \\
\text { consistency }\end{array}$ & $\begin{array}{c}\text { False } \\
\text { positive } \\
\text { rate }\end{array}$ & $\begin{array}{c}\text { Cohen's } \\
\text { kappa }\end{array}$ \\
\hline \multicolumn{7}{|l|}{ Diarrhea prevention } \\
\hline Give salt and sugar solution & 68.1 & $44.5 *$ & 0.36 & 65.8 & $59.0 *$ & 0.27 \\
\hline Give ORS & $72.6 *$ & $25.4^{*}$ & 0.33 & $61.3 *$ & $43.1^{*}$ & 0.23 \\
\hline Zinc tablet/ medicine & 82.2 & 14.3 & 0.25 & 79.8 & 16.3 & 0.14 \\
\hline \multicolumn{7}{|l|}{ Knowledge of pneumonia } \\
\hline Fast breathing & 53.3 & $58.7 *$ & 0.07 & 49.7 & $81.2^{*}$ & 0.06 \\
\hline Chest drawing in & 58.1 & $52.5^{*}$ & 0.20 & 52.4 & $81.5^{*}$ & 0.09 \\
\hline Sound in breathing & $62.0 *$ & $35.7 *$ & 0.12 & $53.3 *$ & $46.3^{*}$ & 0.04 \\
\hline
\end{tabular}

* Significant difference between mentor supported lots and non-mentor supported lots

Table 13 shows the degree of consistency between two surveys for process variables separately for mentor supported lots and non-mentor supported lots. Overall the percentages of consistency were mostly around 65 to 70 percent. The degree of agreement between the two surveys for process variables were mostly fair $(k 0.2$ to $<0.4)$. Mentor supported lots had significantly higher percentage of consistency only for receipt of newborn health leaflet. For non-mentor supported lots significantly higher false positive rates for two out of nine process variables.

TABLE 13 Measurement of consistency of the LQAS-2 data in comparison with validation survey for process variables

\begin{tabular}{lcccccc}
\hline & \multicolumn{3}{c}{ Mentor supported lots $(\mathrm{n}=332)$} & \multicolumn{2}{c}{ Non-mentor supported lots $(\mathrm{n}=336)$} \\
\cline { 2 - 7 } Program related variables & $\begin{array}{c}\% \text { of } \\
\text { consistency }\end{array}$ & $\begin{array}{c}\text { False } \\
\text { positive } \\
\text { rate }\end{array}$ & $\begin{array}{c}\text { Cohen's } \\
\text { kappa }\end{array}$ & $\begin{array}{c}\text { \% of } \\
\text { consistency }\end{array}$ & $\begin{array}{c}\text { False } \\
\text { positive } \\
\text { rate }\end{array}$ & $\begin{array}{c}\text { Cohen's } \\
\text { kappa }\end{array}$ \\
\hline $\begin{array}{l}\text { Source of knowledge } \\
\text { SHG/ Swasth Sakhi }\end{array}$ & 69.0 & $56.0^{*}$ & 0.32 & 65.8 & $74.4^{*}$ & 0.16 \\
$\quad$ Mother-in-law & 70.5 & 20.2 & 0.20 & 72.0 & 25.3 & 0.30 \\
Local doctor & 95.2 & 1.3 & 0.18 & 93.2 & 2.2 & 0.03 \\
AAA & 72.9 & 15.0 & 0.20 & 75.9 & 12.4 & 0.27 \\
Received leaflets/ letters & 58.1 & 50.7 & 0.21 & 55.7 & 53.4 & 0.18 \\
$\quad$ Maternal health leaflet & $61.1^{*}$ & $44.5^{*}$ & 0.25 & $51.5^{*}$ & $56.8^{*}$ & 0.13 \\
$\quad$ Newborn health leaflet & 65.1 & 37.7 & 0.30 & 63.1 & 40.1 & 0.27 \\
$\quad$ Good luck letter & 64.2 & 39.8 & 0.29 & 62.5 & 45.3 & 0.28 \\
$\quad$ Congratulation letter & 69.6 & 41.8 & 0.39 & 65.5 & 50.3 & 0.33 \\
Participated in Health discussion & & &
\end{tabular}

* Significant difference between mentor supported lots and non-mentor supported lots

Overall, the degree of consistency between the two surveys varies between 60 to 70 percent. The degree of agreements were better for practice related variables than knowledge related variables. The difference in percentage of consistency between mentor supported and non-mentor supported lots were not significant for majority of the variables. Similarly, the difference in false positive rates between mentor supported and non-mentor supported lots were also not significant for majority of the variables except for knowledge on child care practices. Therefore, the degree of accuracy of the data did not differ much when mentors were present or not present. 


\section{FINDINGS OF THE OBSERVATIONS OF LQAS INTERVIEWS}

The observations of the LQAS interviews were done to understand the process of administering the LQAS questionnaire in the field. The observations also tried to explore the nature and extent of possible misreporting, if any, during the interview so that the findings can be utilized to train CRDIs better in upcoming rounds of LQAS.

For any field-based interviews, introducing the survey to the respondents is very important. Observations on how the interviewer introduced the survey revealed that the quality of introduction was different. Some of the examples are given below:

Proper introduction: "I am ..... . I am here to conduct a brief interview on maternal and newborn health. It will take about 15 minutes of your time."

Vague introduction: "I am here to ask you a few questions. It will not take long."

No introduction: "Your name please? [Starting with the first question]".

The result of the observation study revealed that although two-third of the interviewer in the mentor supported lot gave the proper introduction, majority of the interviewer in the non-mentor supported lots did not give any introduction.

Figure 3 presents the result of the structured observation of how clearly the questions were asked in LQAS survey. Since the interviewers often asked the question in their own way, an observation was also made how clearly the interviewers were asking the questions. If an interviewer asked and explained the questions without changing its meaning, it was categorized as 'clearly'. If the questions were asked without changing its meaning but the respondent did not understand it was categorized as 'somewhat

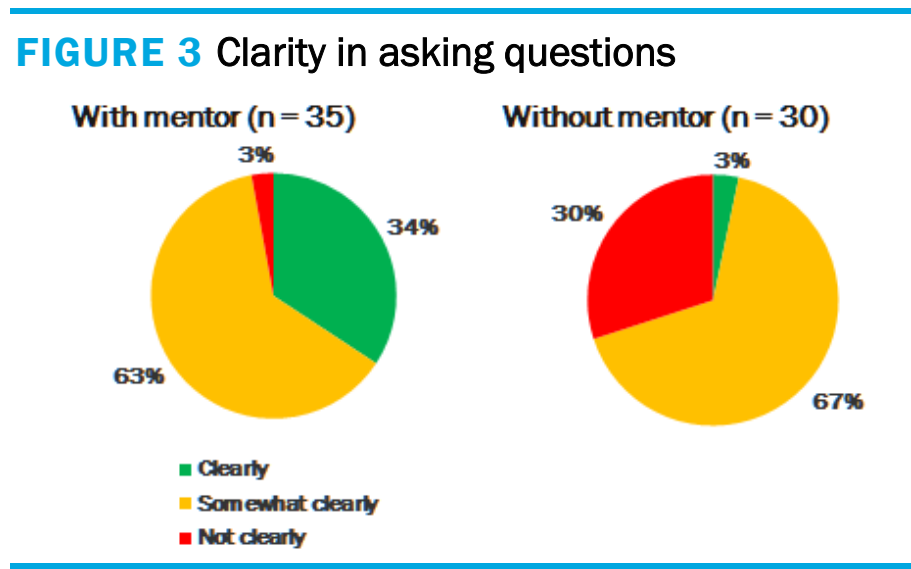
clearly'. If interviewer asked a questions wrongly or asked by changing its meaning, it was categorized as 'not clearly'.

Most of the interviews were categorized into 'somewhat clearly' and the percentages were similar with mentors and without mentor. However over all the interviews with monitored were slightly better in case of mentor-supported interview than the non-mentor interview. For example in about one third of interviews in case of mentorsupported interview the questions were asked 'clearly' where the corresponding figure was obly 3 percent in case of non-mentor

FIGURE 4 Explaining the questions

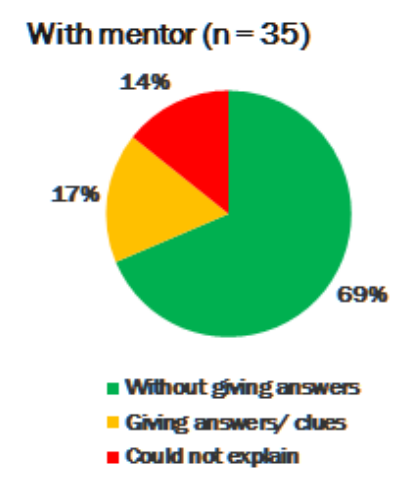

Without mentor $(n=30)$

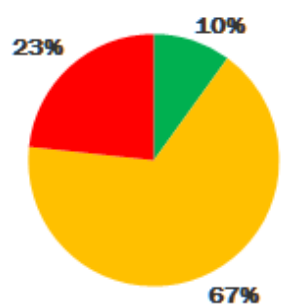
interview. Further, in case of without mentor in 30 percent of the interviews the questions were not asked clearly which was only 3 percent when a mentor was present. 
Figure 4 presents the result of the observation of how good the questions were explained in LQAS survey. Since the interviewers often asked the question in their own way, an observation was also made whether the investigators explained the questions properly or not. It was also observed whether during explanation the investigators were giving away the answers/ clues or not.

Most of the interviews with mentor support (69 percent) were explained without giving away answers or clues. However, in 67 percent of the interviews without mentor the interviewers gave away answers or clues in some of the questions while explaining the questions. Even with mentor support in 14 percent of the interviews the questions were explained wrongly and without mentor support in 23 percent of interviews the questions were wrongly asked.

The following conversation is an example of how the answer clues became the part of explaining the questions and that sometimes led to over-reporting. This conversation was based on asking the question regarding the delivery preparedness.

Question: During your last pregnancy what are the preparations you or your family have done to manage complication?

Interviewer: What are the preparation you or your family have done before your last delivery to avoid any complication?

Respondent: Cloth, hot water

I: Didn't you arrange anything in advance ?

R: $\quad$ Yes, money. [Interviewer coded 'Saved money'.]

I: $\quad$ For what?

R: $\quad$ For car.

I: Why did you need a car?

R: $\quad$ To go to hospital. [Interviewer coded 'Arranged vehicle'.]

I: Did you know which hospital to go?

R: $\quad$ Yes. [Interviewer coded 'Indentified health facility'.]

I: $\quad$ Did you go to hospital alone?

R: $\quad$ No. My M-I-L was with me. [Interviewer coded 'Family member accompanied'.]

Figure 5 presents the result of the observation of whether the interviewers read out the answer keys along with asking the questions. In LQAS survey, interviewers were not instructed to prompt the respondents with different answering options.

With mentor support about 75 percent interview did not prompt for any answers, in 12 cases the interviewers gave away answers in some of the questions and 14 percent of the cases they gave away

\section{FIGURE 5 Read out options}

With mentor $(n=35)$

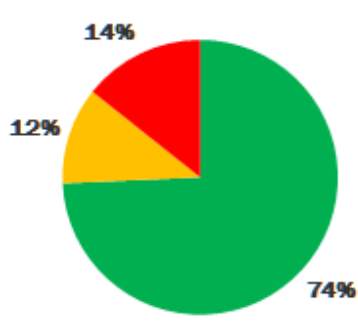

- Not for any question

For few $(<8)$

- For most $(p=8)$ answers in most of the questions even when the mentor was present. The corresponding figures was poorer in case of interview with out mentor and was onserved in case of 7 percent, 60 percent and 33 percent 
Figure 6 presents the result of the observation of whether the interviewers showed pictorial answers to the respondents or not. In LQAS survey, the answer keys in the LQAS form were shown in the pictorial format to facilitate data entry for the interviewer. However, if the respondents see the pictorial answers while answering the question there will be a chance of over reporting.

Generally interviewers did not show pictorial answers to the respondents. Especially when mentors were present during the interview, 80 percent of time interviewer did not show the pictorial answers; while the corresponding figure for interview without mentor was 57 percent. Without mentor interviewer were twice likely to show the answers to the respondents, and 23 percent of time they showed the pictorial answers even for most of the questions ( 8 or more questions).

Figure 7 presents the result of the structured observation of whether the interviewers coded the answers correctly or not. Since the CRDIs need to interpret the responses given by the eligible women and record the code in the survey form there were chances for incorrect coding.

With mentor support, in above 83 percent interviews all the answers were correctly coded. When the mentor support was not available, only 10 percent of interviews were correctly coded for all questions. With the mentor support still in 17 percent of the interviews few questions were coded incorrectly, while without mentor 60 percent of the interviews few questions were coded incorrectly. In this group 30 percent of the cases only few questions were coded correctly.

The observation of the interviews supplemented the findings of the validation study that the interviewers administered the questions more properly with mentor support. The mentor support was made available to the CRDIs in the initial 5 days of the LQAS interviews in a particular block. However, after the withdraw of mentors the interviewers doing those mistakes in data collection which they should not do. This indicates that during the mentor support the interviews were more dependent on the mentors in conducting the interviews instead of learning how to conduct the interviews properly. This indicates need for more intensive data collection training before the next round of LQAS survey.

\section{FIGURE 7 Coded the answers correctly}

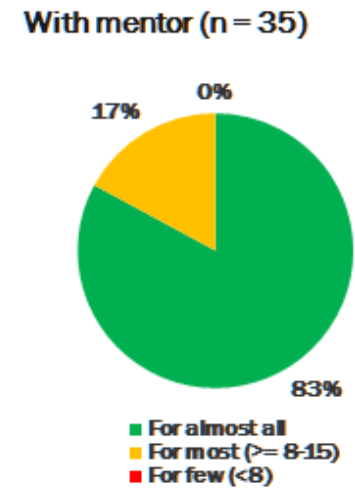

For most $P=8-15)$

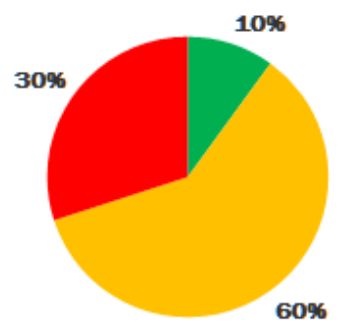

Not for ary question
For few $(<8)$ - Formost $(p-8)$
Without mentor $(n=30)$

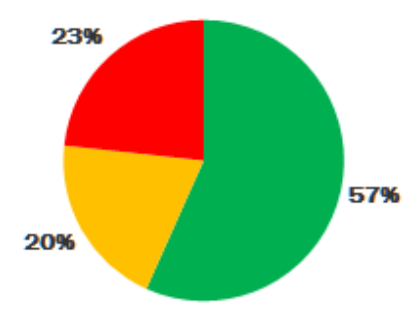




\section{Discussions}

The LQAS surveys in UPBCM project were conducted jointly by PHFI and RGMVP to monitor the program in a periodic basis. The major objective of the first two rounds of the LQAS was to assess the level of maternal and newborn health related knowledge and practices of women of SHGs and SHG households. The other objective of the LQAS surveys was to identify those lots not reaching coverage benchmark so that the block organizations can be informed to take required decisions to achieve project objectives.

The LQAS surveys were conducted by CRDI staff to make it more sustainable even after the end of UPBCM project. Since many of the community member lack experience in how to conduct health related surveys, PHFI provided mentor support to half of the lots. Since LQAS was planned as a community driven survey, it was decided that Population Council should make an independent validation, the M\&E partner of the consortium

The validation study used two approaches: (1) a validation survey by interviewing a subsample of LQAS-2 participants to examine the accuracy of LQAS-2 data and (2) conduct some observation of LQAS- 2 interviews to get some soft data on the process.

The LQAS-2 was conducted in 100 intervention blocks. For the validation survey 25 blocks were selected using a systemic random sampling method out of those 100 blocks. From each block one mentor supported lot and one non-mentor supported lot were randomly selected and all the respondents of that lot were revisited. In total 668 respondents participated in the validation survey, of them 332 were from mentorsupported lots and 336 were from non-mentor supported lots.

The finding of the validation study suggested that there was not much difference in estimates of maternal and newborn health knowledge and practices among the respondents of mentor supported and non-mentor supported lots. The analysis of accuracy of LQAS-2 data between mentor supported and non-mentor supported lots showed the followings:

- Over all there were 60 to 70 percent consistency between the data of LQAS-2 and the validation survey

- The false positive rates vary for different health related variables

- The agreements between the findings of two surveys (as shown by kappa value) were mostly fair $(0.2$ to $<0.4)$ to moderate $(0.4$ to $<0.6)$. However, for some variables especially the knowledge related variables and delivery preparedness the agreement were mostly poor (i.e. < 0.2).

- The consistency between mentor supported lots and non-mentor supported lots were similar for majority of the variables. The variables, which showed statistically significant difference for percentage of consistency between the two types of lots, showed higher consistency in mentor supported lots.

- Similarly the false positive rates between mentor supported lots and non-mentor supported lots were similar for majority of the variables. The variables which showed statistically significant difference for false positive rates between the two types of lots showed lower false positive rates in mentor supported lots.

The observation of the LQAS-2 interviews was done in 7 districts. The observations were made on how the CRDIs introduced the survey, administered the LQAS questionnaire, and recorded the answers. In total 65 interviews were observed of those 35 were mentor supported and 30 interviews were without mentor. The key findings of the observation of the LQAS-2 interviews were following:

- With mentor support the interviewers introduced the survey more properly.

- Regardless of presence or absence of the mentors the interviewers asking the questions in their own way. Sometimes it was necessary to do so to explain the questions properly to the respondents.

- With the mentor support the CRDIs were explaining the question more clearly and without changing its meaning 
- Without mentor CRDIs gave away the answer keys especially when they were struggling to explain the meaning of the questions to the respondents

- Overall the interviewers did not show the pictorial answer to the respondents

- With the mentor support the interviewers recorded correct answer codes

All these findings suggested that the CRDIs needed more training. The training should highlight explaining the meaning of all the questions, and how they should explain to the respondents without giving away the answers. They should be instructed not to record the answers wrongly. Otherwise all these things especially lead to increase of false positive cases and that may hamper the proper monitoring of the project activities. Moreover, CRDIs should be trained about the purpose of the LQAS survey.

These findings of both the validation survey and observation of the interviews confirm that a better training is required for the CRDIs before engaging them for the data collection of the LQAS. Special attention should be given in the training to avoid the reporting of false positive cases.

\section{PROGRAMMATIC RECOMMENDATIONS}

In view of the key findings of the both activities of the LQAS validation study the following programmatic recommendations can be made.

- A longer training of the interviewers (CRDIs) is necessary. The training should include explaining the purpose of the LQAS, which is to monitor the project activities and taking corrective measures, not to evaluate anybody's performance. In the training CRDIs should be informed about the possible common mistakes that they could commit while interviewing and how to avoid those mistakes.

- A prolongs mentor support should be replaced by limited mentoring. It was found that when mentors were not available the mistakes retained by the interviewer. Therefore, instead of making the interviewers dependent on the mentors it is necessary to train them better so that they can properly interview even without mentoring support.

- Small scale validation survey can be done to measure the error level of the LQAS survey for taking corrective steps, if necessary. 


\section{Appendix}

\section{Appendix 1}

महिला प्रश्नावली (जिनकी डिलीवरी पिछले 6 महीने में हुई है)

\begin{tabular}{|c|c|c|c|c|c|}
\hline ब्लॉक & & चायत & सी वी का नाम & \multicolumn{2}{|l|}{ आई एस सी का नाम } \\
\hline \multicolumn{3}{|c|}{ 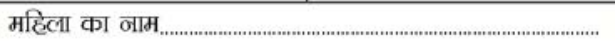 } & \multicolumn{3}{|c|}{ 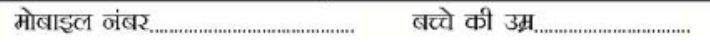 } \\
\hline \multicolumn{2}{|c|}{ क्या आपको पढ़णा लिखणा आता है? } & हौं (1) नही (2) & सिर्फ पढ़्णा (3) & (4) & \\
\hline \multicolumn{3}{|c|}{$\begin{array}{l}\text { आपके पखिवार से कौन समूह का सदस्य है? } \\
\text { आप स्वयं } \quad . . . . . .1 \text { आपकी सास } . . . .2 \text { अन्य कोई ........ }\end{array}$} & \multicolumn{2}{|c|}{$\begin{array}{l}\text { सहयोगी सदस्व: } \\
\text { एल,क्यू.एएस, मेन्टर (1) सी.आर,डी.सी. (2) }\end{array}$} & अकेला (3) \\
\hline
\end{tabular}

कृपया किसी भी प्रश्न का उत्तर पढ़कर न बताएं। पूछे

1. विछ्ली गर्भावस्था के दौरान आवने कितनी बार प्रसव पूर्व जाँचें करवाई थी?

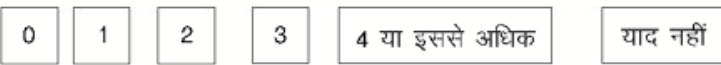

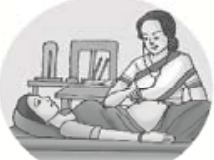

2. गर्भावस्था के दौरान आपने कितनी आयरज की गोलियां खाई थी?

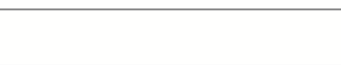

3. आपके सबसे छोटे बच्चे का जन्म (डिलीवरी) कहाँ हुआ था?
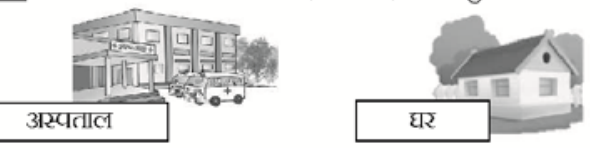

उन्य

4. गर्भावस्था के दौरान या डिलीवरी के बाद खतरे के कौन-कौन से लक्षण है जिनके लिए महिला को स्वास्थ्य केन्द्र/अस्पताल जाजा चाहिए
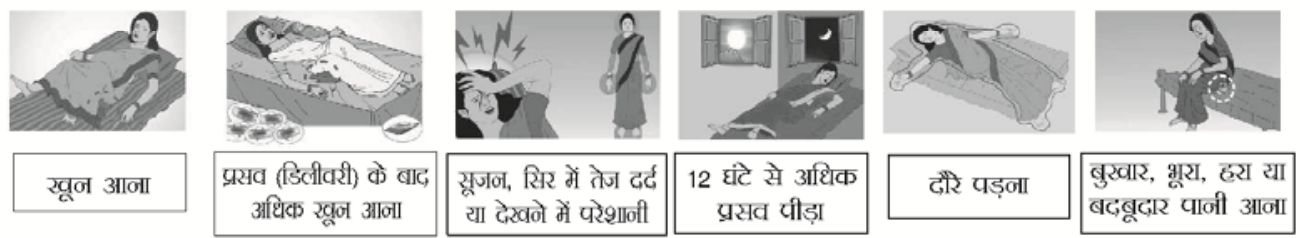

पता

प्रसव (डिलीवरी) के बाद सूजन, सिर में तेज दट्ठ अधिक खूल आना या देखणे में परेशानी

प्रसव पीड़ा

5. पिछली गर्भावस्था के दौसन आपने। परिवार के प्रसव की जटिलताओं से निपटने के लिए पहले से कौन-कौन सी तैयारियां की शी?

अस्पताल की पहचाल

वाहल की व्यवस्था

पैसे की बचत

घर पर बच्चों की

अस्पताल जाते समय परिवार
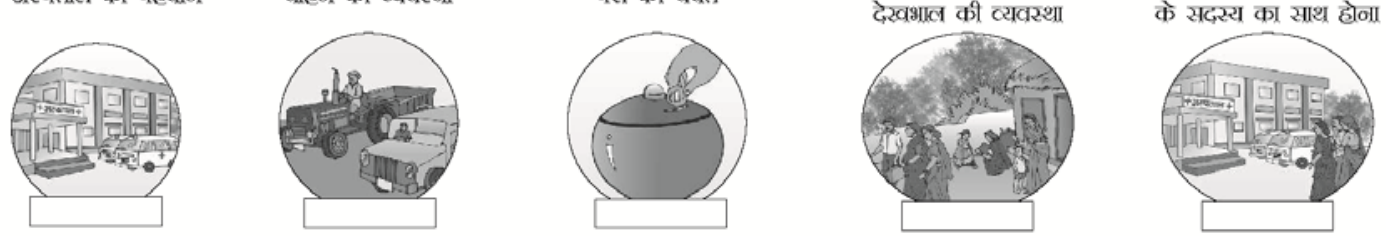

6. बतजात शिशु को किज जटिलताओं का सामला करना पड़ सकता है जिसके लिए उसे तुरंत अस्पतालस्वास्थ्य केन्द्र ले जाना चाहिए?
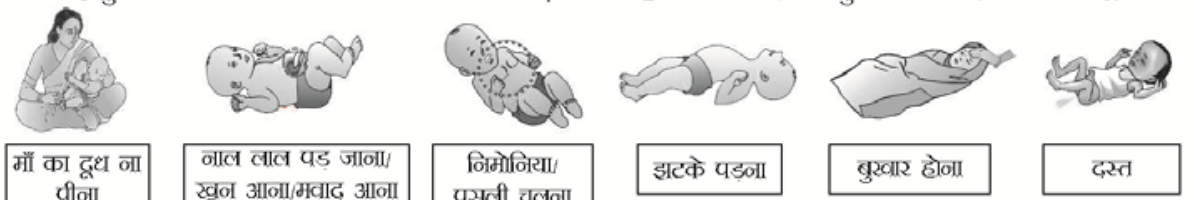

पता

माँ का दूध ला

नाल लाल पड़ जाना/
ख्वन आला/मवाद आणा

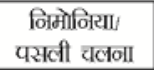

इट्के पड़ना

बुख्वार होना

नही
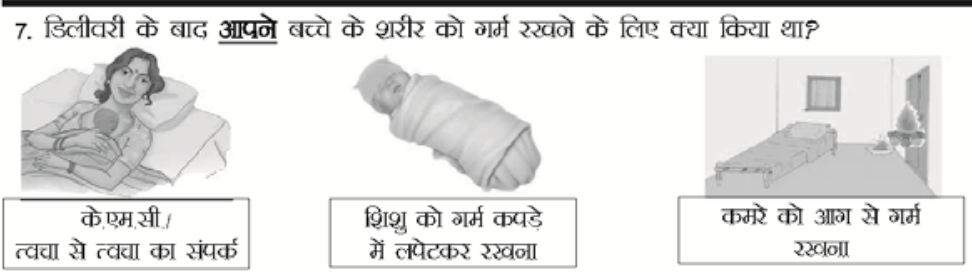

कुछ नही 
8. वाजजात शिशु को गर्म रखणे के लिए किस प्रकार से के एम सी (त्वचा से त्वचा संपर्क) दे सकते है?

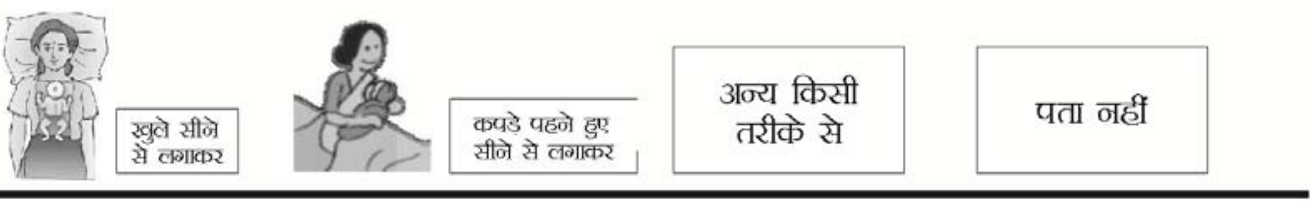

9. पिछले 24 घंटे में आपने शिशु को अपने दूध के अलावा और वया-वया खिलाया-पिलाया था?

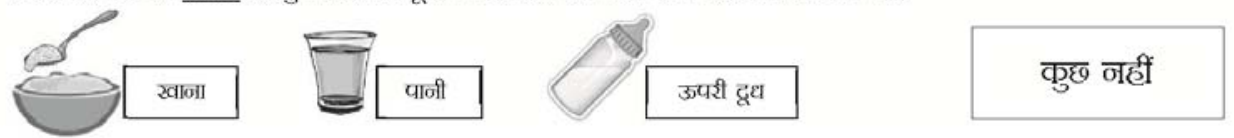

10. जन्म के बाद नवजात को पहली बार कब नहलाया गया था?

\begin{tabular}{|l|l|l|l|l|l|l|l|}
\hline 1 दिन & 2 दिन & 3 दिन & 4 दिन & 5 दिन & 6 दिन & 7 दिन & ? \\
\hline
\end{tabular}

11. डिलीवरी के बाद आपणे शिशु की नाल सुखाणे के लिए वरा लगाया था?
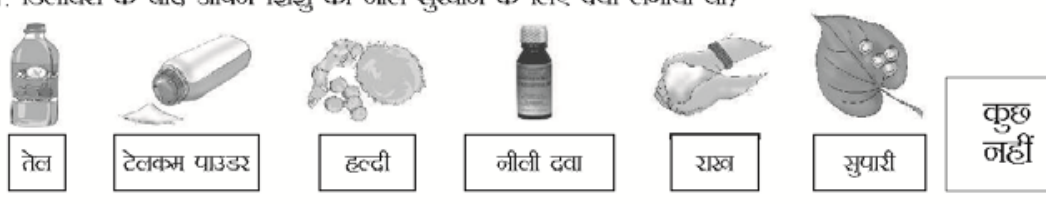

पता नहीं

12. डिलीवरी के बाद, पहले हपते (7 दिन के अंदर) आशा बहल आपकी या आपके बव्वे की कितनी बार जांव करने आयी थी?

\begin{tabular}{|l|l|}
\hline 1 & 2 \\
\hline & 3 से अधिक $\quad$ नही आयी \\
\hline
\end{tabular}

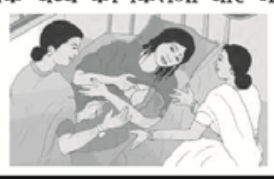

13. अगर किसी बचते को दस्त (डायरिया) लग जाए तो आप दस्त के उपचार के लिए वरा सलाह देंगी?
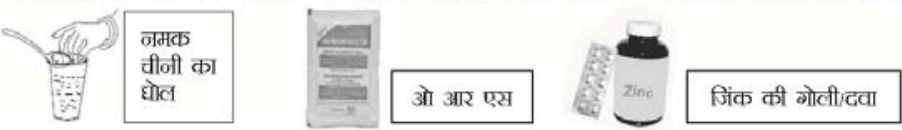

पता कहीं

14. निमोनिया के क्या लक्षण है?

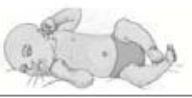

खांसी के साथ तेज सांस वलना
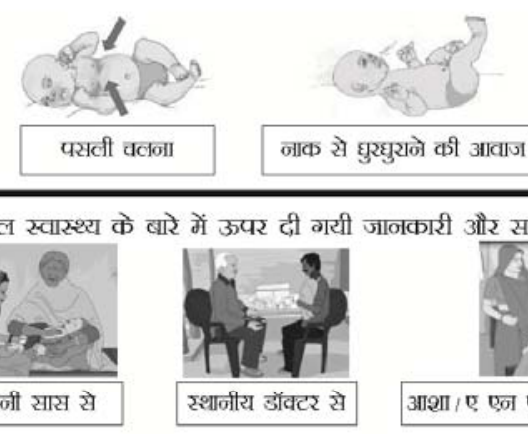

अन्य

पता नहीं

15. आपको मातृत्व, बवजात और बाल स्वास्थ्य के बारे में ऊपर दी वरी जानकारी और सक्देश किसके दिया?

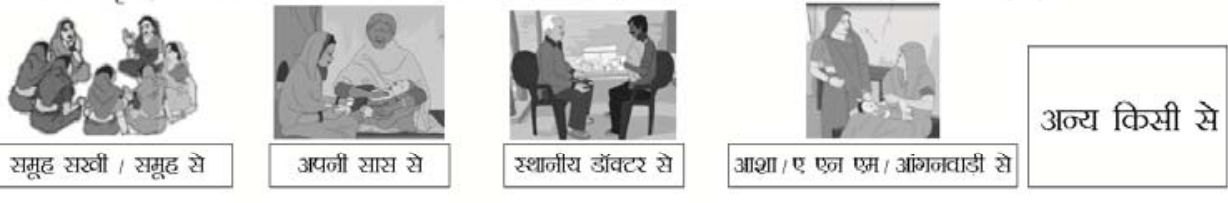

16. पिछले 6 महीने में आपको इनमें से वरा-वया मिला है? (दिखाकर पूछें)

मातृत्व स्वास्था
अवज्ञात स्वास्थ
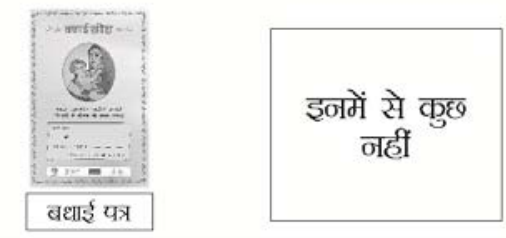

17. विधली गर्भावस्था के दौयन क्या आपने किसी समूह बैठक में हिस्सा लिया जहाँ आपको स्वास्थ्य सक्देश मिला?
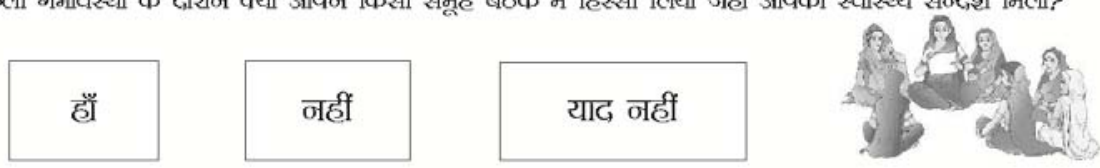


\section{LQAS VALIDATION}

\section{OBSERVATION SHEET}

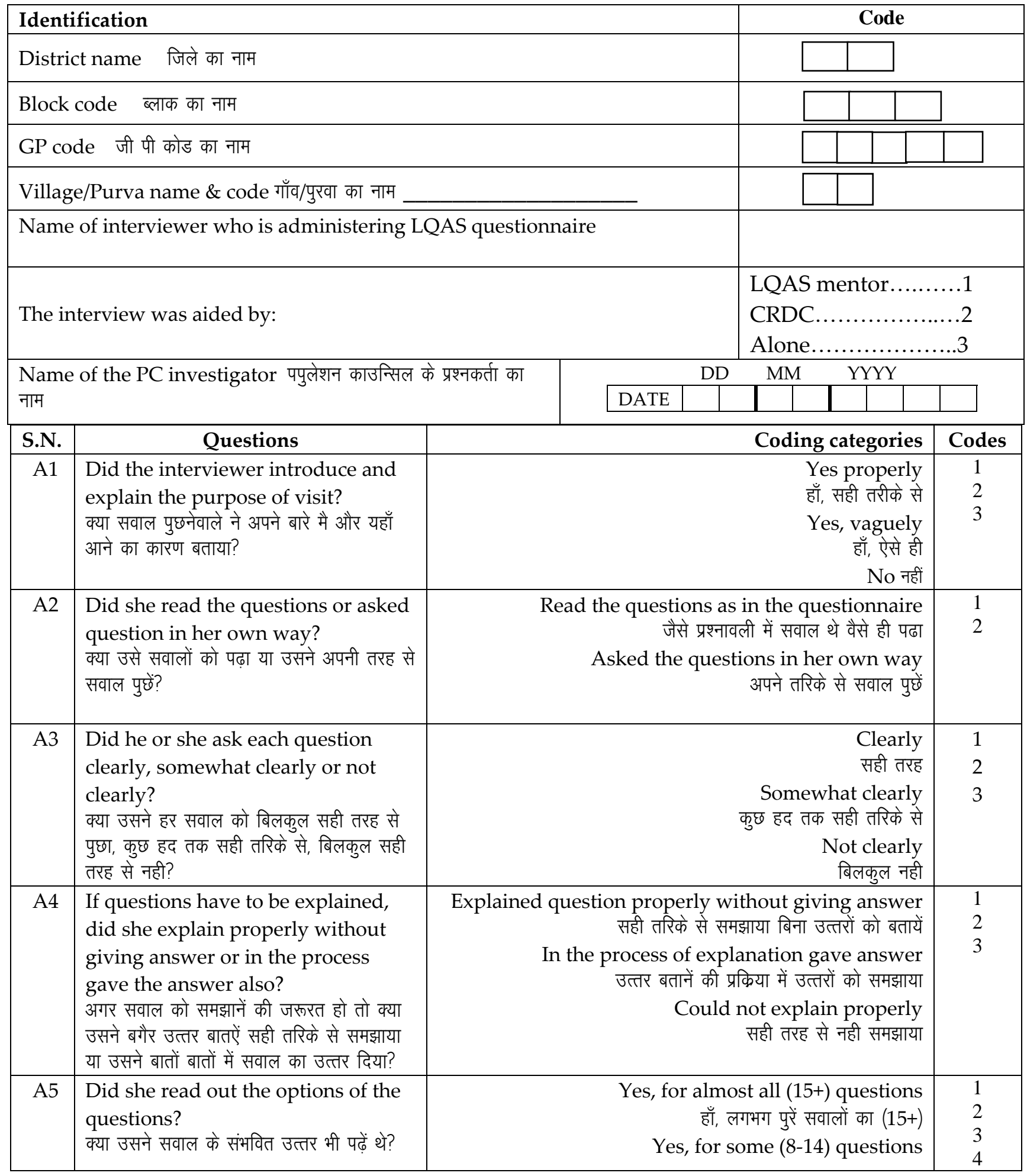




\begin{tabular}{|c|c|c|c|}
\hline S.N. & Questions & Coding categories & Codes \\
\hline & & $\begin{array}{r}\text { हाँ, (8-14) सवालों का } \\
\text { Yes, for some (1-7) questions } \\
\text { हाँ,(1-7) सवालों का } \\
\text { No, did not read options for any question } \\
\text { किसी भी सवाल का उत्तर नही पढ़ा }\end{array}$ & \\
\hline A6 & $\begin{array}{l}\text { Did he show the pictures of } \\
\text { questionnaire while asking the } \\
\text { questions? } \\
\text { क्या सवाल पुछते समय उसने सवालों को दर्शाने } \\
\text { वाले चित्र भी दिखाऐं? }\end{array}$ & $\begin{array}{r}\text { Yes, for almost all (15+) questions } \\
\text { हाँ, लगभग सभी सवालों के (15+) } \\
\text { Yes, for some (8-14) questions } \\
\text { हाँ, (8-14) सवालों के } \\
\text { Yes, for some (1-7) questions } \\
\text { हाँ, (1-7) सवालों के } \\
\text { No, did not show picture for any question } \\
\text { किसी भी सवाल के लिए चित्र नही दिखाया }\end{array}$ & $\begin{array}{l}2 \\
3 \\
4\end{array}$ \\
\hline A7 & $\begin{array}{l}\text { Did she fill the answer correctly? } \\
\text { क्या उसने सही जवाब कोड किये }\end{array}$ & $\begin{array}{r}\text { Yes, for almost all (15+) questions } \\
\text { हाँ, लगभग पुरें सवाल (15+) } \\
\text { Yes, for some (8-14) questions } \\
\text { हाँ, (8-14) सवालों का } \\
\text { Yes, for some (1-7) questions } \\
\text { हाँ, (1-7) सवालों का } \\
\text { No, did not fill answer correctly for any question } \\
\text { किसी भी सवाल का सही उत्तर नही भरा }\end{array}$ & $\begin{array}{l}1 \\
2 \\
3 \\
4\end{array}$ \\
\hline A8 & $\begin{array}{l}\text { Is a compiled list of eligible woman } \\
\text { (EW) available with the } \\
\text { interviewer? } \\
\text { क्या प्रश्नकर्ता के पास योग्य महिलाओं की सुची } \\
\text { उपलब्ध थी? }\end{array}$ & $\begin{array}{l}\text { Yes हाँ } \\
\text { No नहीं }\end{array}$ & $\begin{array}{l}1 \\
2\end{array}$ \\
\hline
\end{tabular}



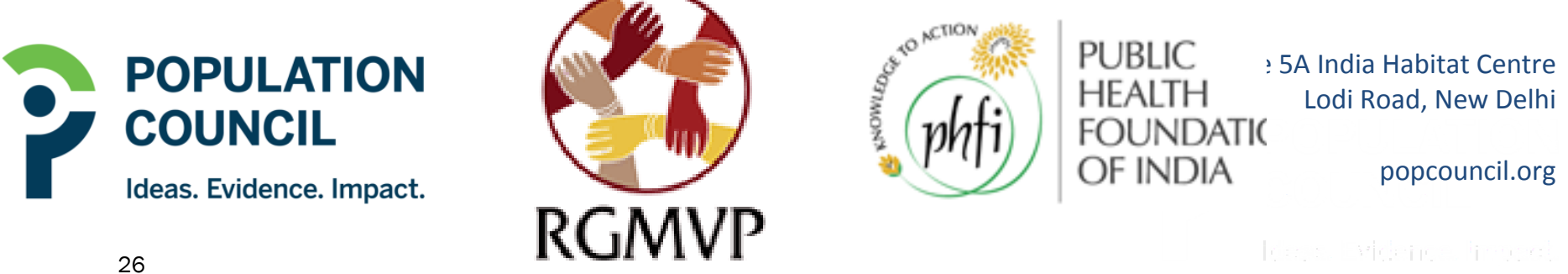